\title{
The Domination of Cultural and Symbolic Capital in the Preservation of Temple Heritage Architecture through a Restoration Approach in Bali, Indonesia
}

\author{
I Kadek Pranajaya ${ }^{1}$, Ngakan Ketut Acwin Dwijendra ${ }^{2, *}$ \\ ${ }^{1}$ Institute Desain and Bisnis Bali, Indonesia \\ ${ }^{2}$ Faculty of Engineering, Udayana University, Bali, Indonesia
}

Received June 6, 2021; Revised August 10, 2021; Accepted August 22, 2021

\section{Cite This Paper in the following Citation Styles}

(a): [1] I Kadek Pranajaya, Ngakan Ketut Acwin Dwijendra, "The Domination of Cultural and Symbolic Capital in the Preservation of Temple Heritage Architecture through a Restoration Approach in Bali, Indonesia," Civil Engineering and Architecture, Vol. 9, No. 6, pp. 1744-1753, 2021. DOI: 10.13189/cea.2021.090608.

(b): I Kadek Pranajaya, Ngakan Ketut Acwin Dwijendra (2021). The Domination of Cultural and Symbolic Capital in the Preservation of Temple Heritage Architecture through a Restoration Approach in Bali, Indonesia. Civil Engineering and Architecture, 9(6), 1744-1753. DOI: 10.13189/cea.2021.090608.

Copyright $\mathrm{C} 2021$ by authors, all rights reserved. Authors agree that this article remains permanently open access under the terms of the Creative Commons Attribution License 4.0 International License

\begin{abstract}
Architecture plays an essential role in various aspects of life and becomes evidence in tracing the nation's history. Efforts to encourage the preservation of historical buildings, including preserving the architectural style of Balinese temples, have been carried out by many people. The traditions and local wisdom of traditional Balinese architecture inherited from the people in Bali can be used as cultural capital and symbolic capital for the development and preservation of traditional Balinese architecture. Restoration activities at the Temple of Guwang Village, Gianyar Bali, Indonesia aim to restore the building as closely as possible to its original form by prioritizing aspects of preservation so that the carving patterns, ornaments, and characteristics of traditional Balinese architecture in the temple still survive as evidence of civilization and historical developments. The exploratory qualitative method [24] was used in this study by triangulation of data collection, namely from documents, observations and in-depth interviews. This research method aims to analyze the dominance of cultural and symbolic capital in the restoration process carried out by the people of Guwang Village. The results of this study will undoubtedly enrich the vocabulary of researchers and readers in understanding the process of restoring the architectural heritage of temples in Bali, and in addition, to offer knowledge in the scientific area of architectural culture and to improve and add
\end{abstract}

understanding, both for authors and readers.

Keywords Domination, Cultural Capital, Symbolic Capital, Preservation, Heritage Architecture, Restoration

\section{Introduction}

Cultural heritage is a nation's cultural wealth that is important for understanding and developing history, science, and culture, so it needs to be protected and maintained to foster awareness of its identity. Cultural heritage buildings as cultural resources have an essential meaning and role in strengthening local and national identities [5]. Cultural heritage is the nation's cultural wealth as a form of thought and behavior in human life. It is crucial for understanding and developing history, science, and culture in society, nation, and state [29][30][31]. It needs to be preserved and managed appropriately through protection, development, and utilization to advance national culture for the greatest prosperity of the people [27][28].

One way to protect and maintain cultural heritage objects/sites is to restore restoration. The aim is to restore the authenticity of objects/cultural heritage sites from an archaeological, historical, and technical perspective. 
Through cultural and symbolic capital, the importance of historical buildings, especially the heritage architecture of the temple, is now starting to be reinforced through restoration measures.

The temple is one of the architectural works of ancient relics that serve as a worship place for Hindus. Pura, as one of the Balinese people's local wisdom, is often associated with the identity of a region and cultural heritage. Through the cultural and symbolic strengths of the people in Bali, they have carried out architectural restoration activities of the Balinese temple heritage to restore the building's integrity, including restoring its ornaments and carvings to their original state [12][22].

Restoration is very much needed because historic buildings can be enjoyed throughout the ages, and cultural heritage buildings because contain aesthetic, architectural, form, and spatial values. The values contained in historical buildings can be passed on to future generations as evidence of the history and culture of a nation).

However, lately, we still encounter temple buildings being renovated without paying attention to the historical value contained in them because it often raises opinions in the community that temples are not part of a heritage building that is hundreds to thousands of years old. In the restoration of temples, this view often leads to new shapes and materials that are less guarded and maintained. There have been many changes in the temple structure and the details of its ornaments, even though the temple building has a high historical value that is hundreds of years old.

The decline in social assistance funds by the provincial and district/city governments in Bali through proposals submitted without being accompanied by in-depth studies sometimes causes many temples in Bali to be dismantled without returning them to their original form and ornament. This action has unwittingly removed the traces and historical value contained in the building.

It is necessary to preserve the heritage architecture through restoration activities so that historical values can be maintained and passed on to future generations as evidence of the history and culture of a nation. The bureaucracy of social assistance to a society full of interests tends to eliminate traces of the culture, history, and civilization of the temple's heritage architecture and has committed symbolic violence.

Guwang Village is one of the villages located in Sukawati Subdistrict, Gianyar Regency, which has many heritage buildings over 50 years old, one of which is the Village Temple and Puseh Temple are estimated to be more than 200 years old. Through the capital of Guwang Village, Sukawati Gianyar agreed to carry out the restoration of the walls and bale kulkul at the Desa Temple and Puseh Temple. This research will analyze the dominance of cultural and symbolic capital in restoring the temple in Guwang Village, Sukawati, Gianyar Regency.

\section{Research Methods}

This research was conducted using a qualitative exploration method. Qualitative research aims to see all phenomena that occur in research subjects as a whole, such as behavior and perception, by describing them in the form of words, symbols, and language in a particular condition that occurs naturally and using scientific methods [3][23].

Qualitative research methods aim to obtain in-depth, meaningful, and naturalistic data and describe and analyze phenomena, events, social activities, attitudes, beliefs, perceptions, and thoughts of people individually or in groups [24]. This study was to observe the restoration process carried out in the Village Temple and Puseh Desa Guwang, Sukawati, Gianyar Regency.

Data was collected using triangulation methods, namely in-depth interviews, observations and from ancient documents and supporting literature. Data collection techniques are carried out by recording, interviewing, documenting, and observing the restoration activities of the temple's heritage architecture from planning, implementation, and inauguration ceremonies [25]. Data collection was carried out by directly heading to the research location, namely in Pura Desa and Pura Puseh, Sukawati, Gianyar Regency. Through direct observation in the field, researchers can observe objectively, record, document temple restoration activities through the restoration process.

In-depth interviews were conducted with selected resource persons, namely architects/undagi, community leaders, and several communities through focus group discussions. In connection with the purpose of the study, it was to explore the dominance of cultural and symbolic capital owned by the people of Guwang Village, so that observations and comparative studies of similar temples were also carried out on restoration activities at Pura Desa, Pura Puseh and other temples as a reference for the author in the analysis of the discussion. Literature data, field data, documentation, observations and interviews were then analyzed by describing sequentially to a conclusion [26]. The results of this study will certainly enrich the vocabulary of researchers and readers in understanding the process of restoring the architectural heritage of temples in Bali. Research can be used as a reference data for the community or parties who want to restore the temple's heritage architecture through restoration.

\section{Result and Discussion}

\subsection{Principles of Temple Heritage Architectural Restoration}

Law No.11 of 2010 [5] concerning Cultural Heritage states that restoration is an effort to restore the condition 
of cultural heritage buildings accurately to their originality by removing additional elements/components and materials and replacing missing parts/components to become like their original form.

Article 77 in Law No.11/2010 states that restoration of cultural heritage must take into account: a) authenticity of materials, shape, layout, style, and working technology b) original conditions with the slightest degree of change c) use of techniques, methods, and non-destructive materials d) the executor's competence in restoration. e) Restoration must allow adjustments in the future by taking into account the community's safety and the safety of cultural heritage.

A cultural heritage restoration activity must be controlled with in-depth and professional studies to assess a macro problem, develop plans, analyze specific patterns, and develop a planning strategy. The planning stages of the restoration of cultural heritage have steps starting from data collection/inventory, data compilation and processing, cultural meaning assessment, prioritization and ranking, strategy and policy formulation, program and planning stages, and the final step in the form of financing and implementation [2].

Ministerial Regulation No. 01/PRT/M/2015 [6] concerning preserved cultural heritage buildings in Article 10 states that the implementation of the restoration of preserved cultural heritage buildings through activities: a) preparation, b) technical planning c) implementation, d) utilization, and e) demolition.

\subsection{Temples as Heritage Architecture}

Bali is known as the island of a thousand temples because the majority of its population is Hindu. The temple is one of the architectural works of ancient relics that serve as a worship place for Hindus [8][10][13]. As one of the local wisdom of the Balinese people, Temple is often associated with the identity of a region and cultural heritage [19][20]. Regional Regulation No. 5 of 2005 [7] concerning Requirements for Building Architecture states that temples are included in heritage architecture because they are considered clear evidence of recorded history from the past to the present.
In Bali, there are 4 (four) types of temples, namely Kahyangan Jagat Temple and Dang Kahyangan Jagat Temple, Kahyangan Desa Temple, Swagina Temple, and Kawitan Temple. Not a few temples in Bali, have changed both physically and non-physically so that people today do not know the value and historical meaning of a temple site. Ornaments and reliefs that have historical significance are often replaced with contemporary shapes and materials [11].

Many factors can be said to be the cause of the change or development of a temple, including: (1) the absence of complete documentation about the existence of a temple; (2) the community's understanding is still minimal about the process of repairing the temple; (3) the absence of written rules in the form of, awig-awig or peraarem (written rules), regarding the procedures for the temple repair process; (4) the community's desire to renovate temples practically and inexpensively; and (5) community insensitivity to their territorial identity [4][21].

\subsection{Restoration of Walls and Bale Kulkul Village Temple and Puseh Temple, Guwang Sukawati Village, Gianyar}

The process of restoring the walls and bale kulkul Pura Desa and Pura Puseh Desa Guwang Sukawati Gianyar is broadly classified as a significant level restoration because the renovations were carried out to raise the foundation of the building due to sinking due to the height of the highway and a number of carvings and Balinese style ornaments. The restoration emphasizes the aspect of preservation by reusing the materials used and replacing damaged materials [16][18].

Restoration of the walls and bale kulkul Pura Desa and Pura Puseh Desa Guwang Sukawati Gianyar begins from the planning and documentation stages by involving a team of architects and cultural heritage experts. After obtaining an agreement about the restoration planning in the technical document, the next step is a ritual procession by spiritually moving the wall building and the balé kulkul in a set of ceremonies.

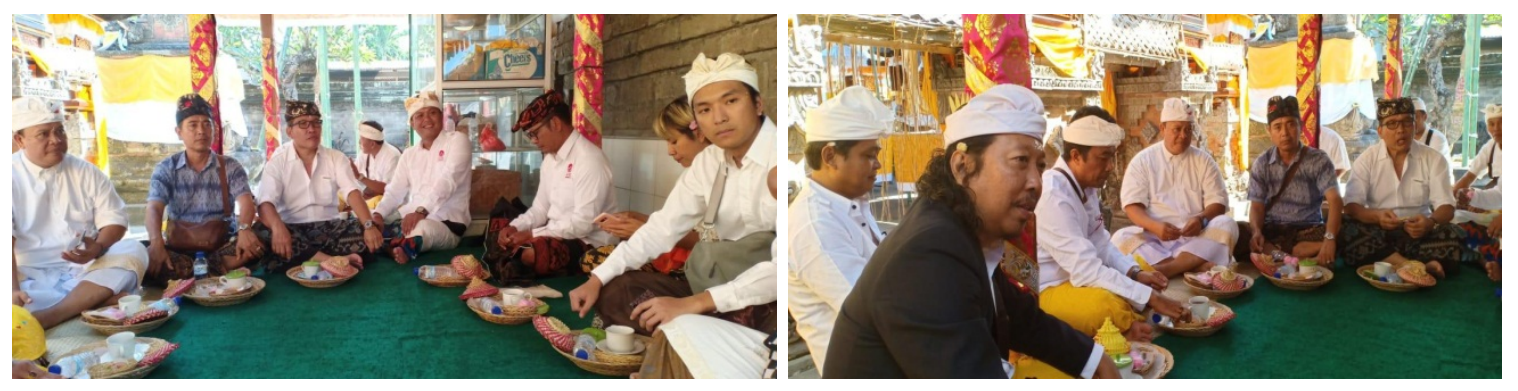

Source: Author, 2019.

Figure 1. Restoration Planning Stage (discussion \& presentation of planning results) 
The next stage is the implementation of restoration. At this stage the existing building will be demolished by opening one by one the wall material and the bale kulkul and giving the numbering so that later in installing the ornament, it can be done precisely in accordance with the original position. The carvings that were previously removed were reassembled using clay from Pejaten Village, Tabanan Regency.

All material removed is recorded, marked and documented. Striving for the carving patterns and ornaments of traditional Balinese architectural carvings is that they are still intact and in accordance with the initial conditions. Materials that cannot be used are replaced with similar materials so that the historical and ornamental values as characteristics of civilization can be maintained [14][17]. The restoration process is fully carried out by collecting data on the details of the ornaments and carvings according to the existing conditions, which have been done carefully and with great patience. The image below shows the restoration process.

After completing the demolition of the existing building, it is continued with the process of determining the layout. This stage of determining the layout is traditionally accompanied by a ceremonial procession called nyukat genah (measuring the land). The next stage is the foundation excavation work [15]. This stage of excavation work is also accompanied by a ceremonial procession called ngaruwak. After the ngaruwak ceremony, it is continued with the laying of the first stone or called mulang dasar, namely the installation of the first stone accompanied by the offering ceremony. With the implementation of this basic mulang dasar, the next stage of work continues with construction work, which begins with the work of the foundation pairing and stone masonry.
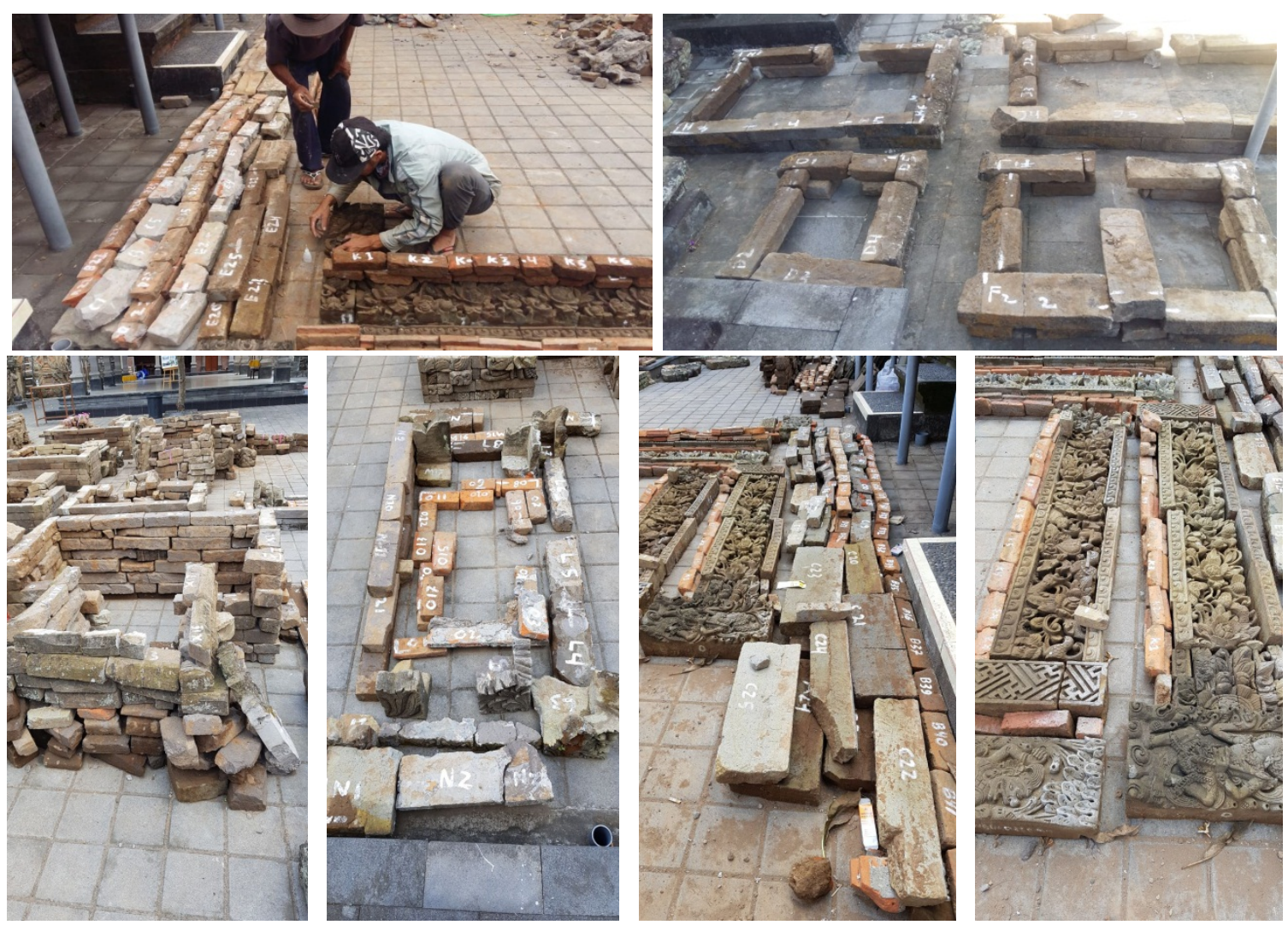

Source: Author, 2019.

Figure 2. Opening one by one the ornaments and numbering them 
This stage of the work of the couple is entirely technical without any ritual procession.

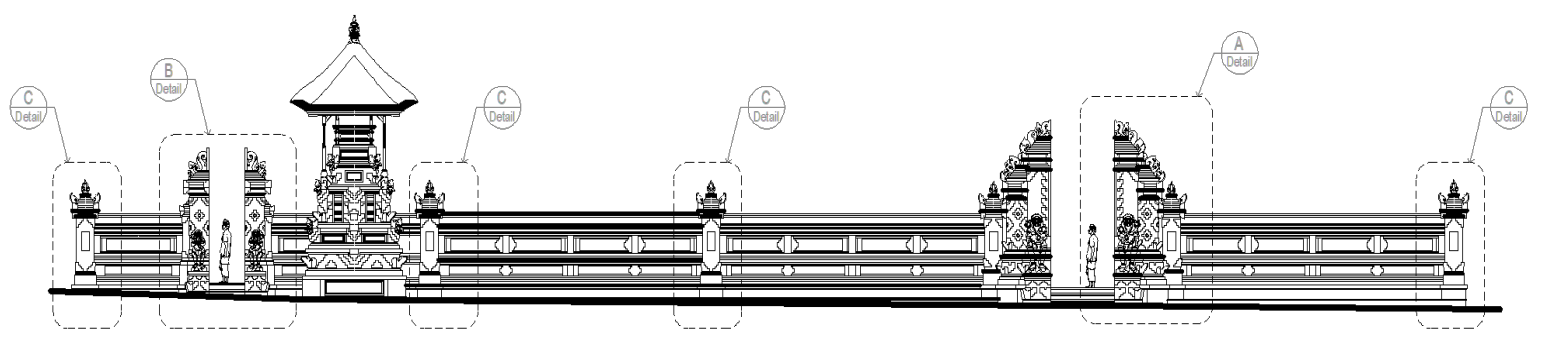

Source: Architect Team IAI Bali, 2019.

Figure 3. Front View of the Wall and Bale Kul Kul, Results of the Restoration Planning by the Architect and Cultural Heritage Expert Team
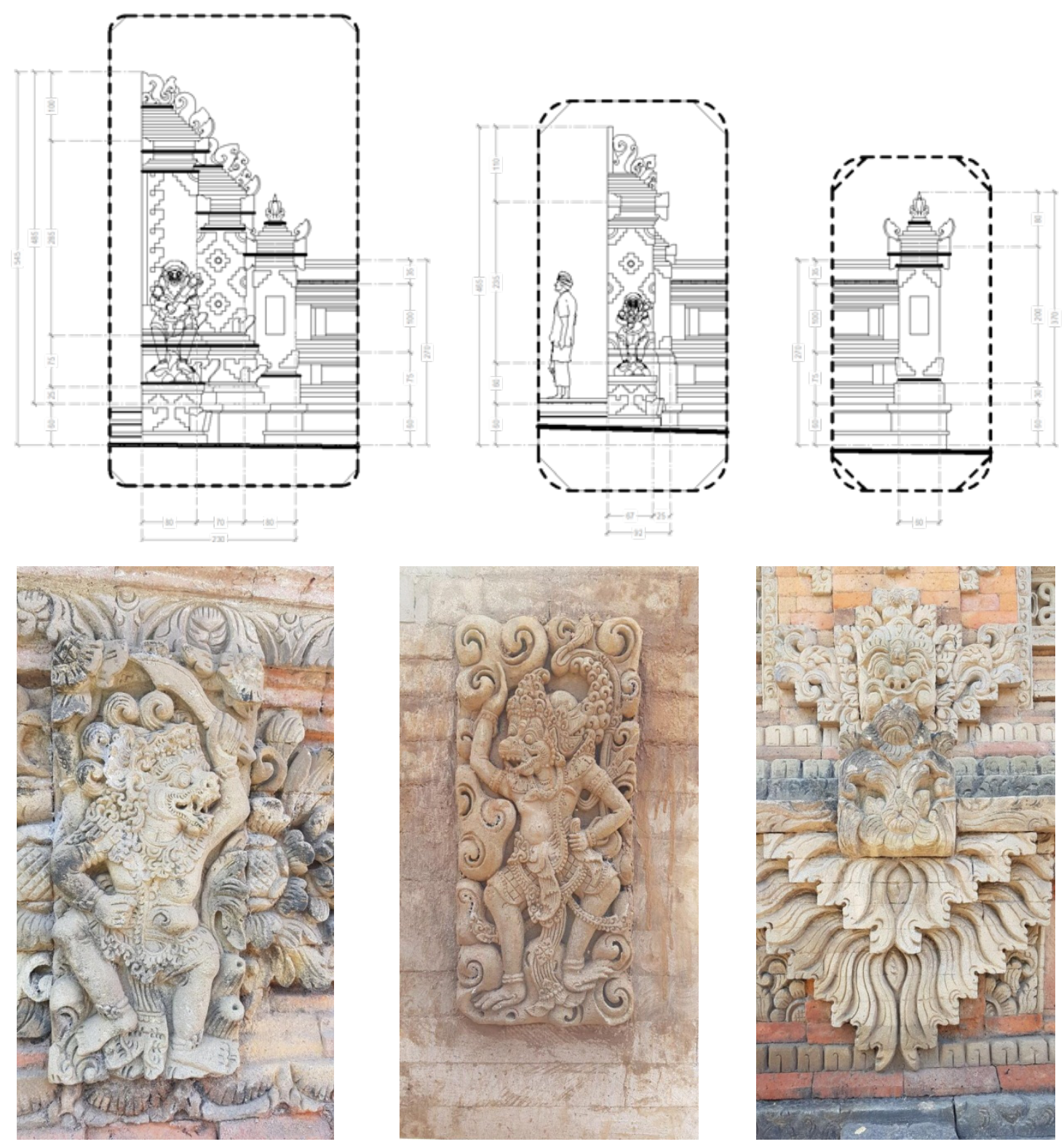

Source: Architect Team IAI Bali, 2019.

Figure 4. Candi Bentar Details \& Ornament Documentation, Results of the Restoration Planning for the Architect and Cultural Heritage Expert Team 

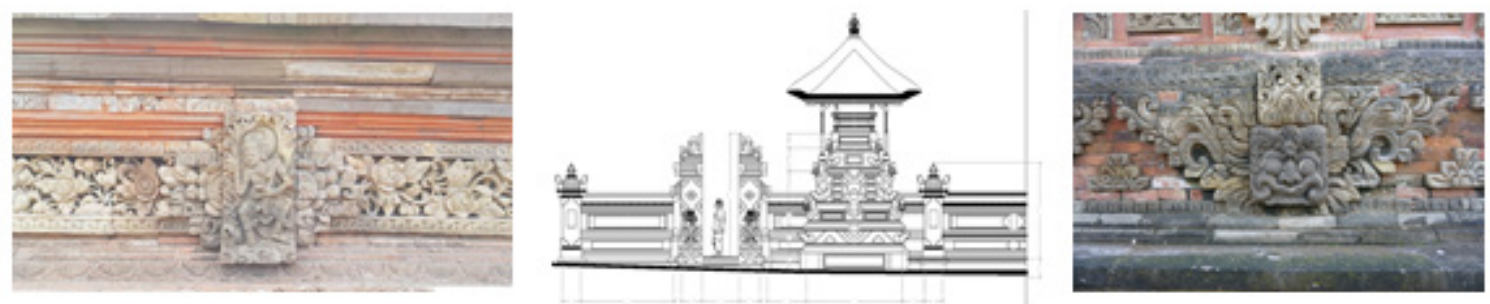

Source: Architect Team IAI Bali, 2019.

Figure 5. Walls, the Candi Bentar dan Bale Kulkul, Results of the Restoration Planning for the Architect and Cultural Heritage Expert Team
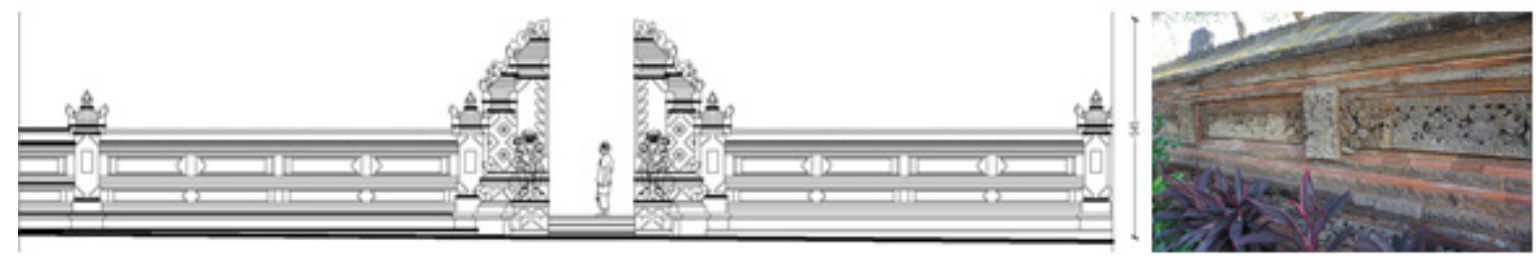

Source: Architect Team IAI Bali, 2019.

Figure 6. Front View of the Walls and Candi Bentar, Results of the Restoration Planning by the Architect and Cultural Heritage Expert Team
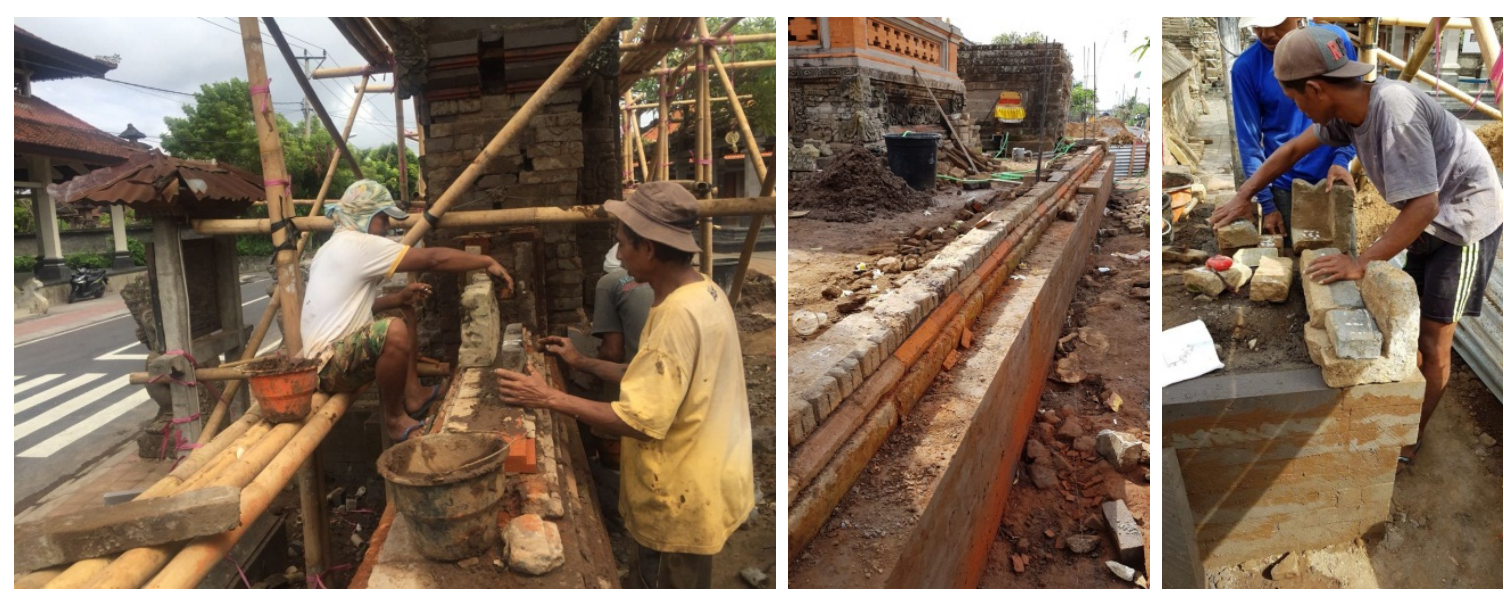

Source: Author, 2019.

Figure 7. Putting back the ornaments one by one with clay

The final stage of the physical work of the restoration process is the finishing of the walls, candi bentar, and bale kulkul. Buildings made of brick and solid are carved and finished with original engravings, while the wooden parts are finished with protective polishing, paint and, prada. The palm fiber roof cover is also neatly finished by cutting the edges and combing it with water coating and protective materials.

When the entire restoration is said to be complete, the next stage is the inauguration ceremony/melaspas coupled with the piodalan ceremony or the anniversary of the temple, which has been ongoing for a long time. 

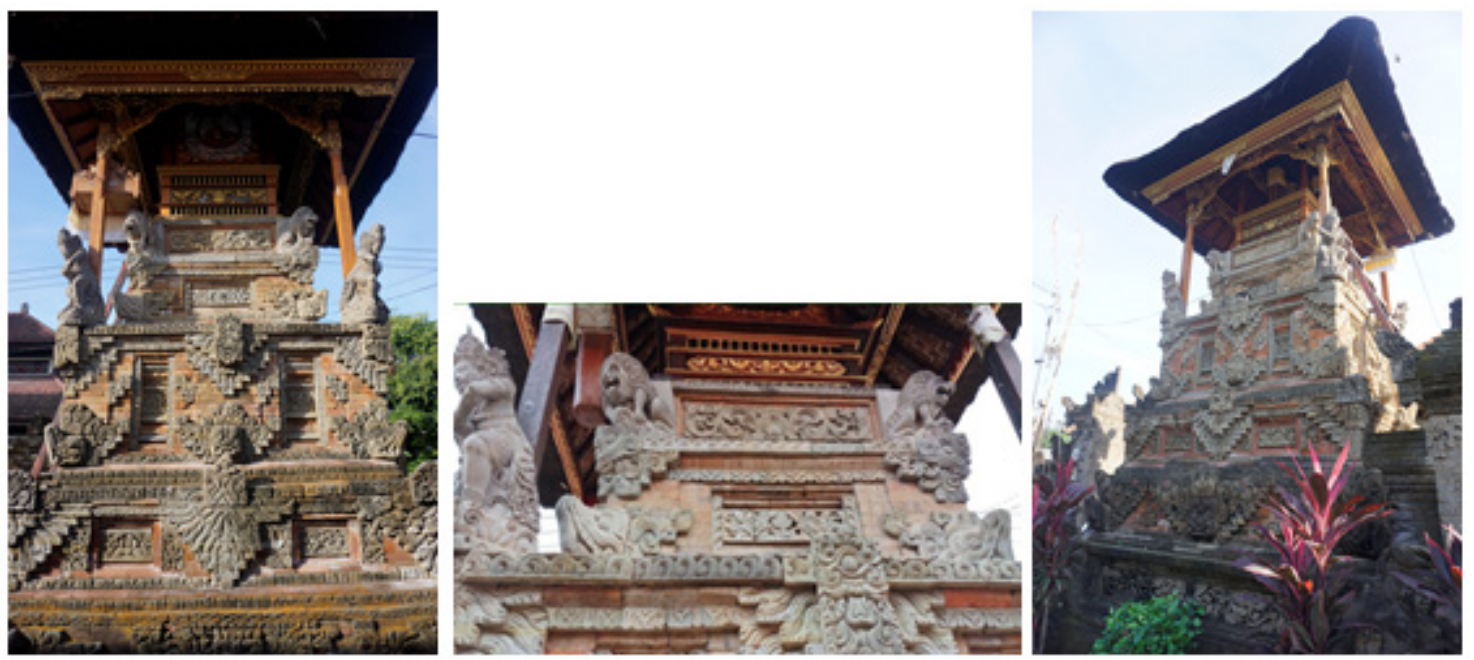

Source: Author, 2019.

Figure 8. Finishing Stage

\subsection{The Domination of Cultural Capital and Symbolic Capital in the Preservation of Heritage Architecture of Temples in Bali}

The traditions and local wisdom of traditional Balinese architecture that are inherited from the people in Bali can be used as cultural capital and symbolic capital for the development and preservation of traditional Balinese architecture so that symbolic violence does not occur which leads to the extinction of traditional Balinese architectural values. Even Law Number 5 of 2017 [5][7] concerning the Advancement of Culture has shown efforts to advance a variety of local cultures, the process of which is carried out through the protection, development, utilization and fostering of Indonesia's national culture to strengthen the nation's economy. According to (Bourdieu, 2016), capital is not only interpreted as economic ownership, but has been developed into social, cultural and symbolic capital. Capital (capital) is what allows us to get opportunities in life. Capital can be obtained if people have the right habitus in social practice. Capital plays a fairly central role in social power relations. Agents acting in their daily lives are influenced by the structure or rules that exist in society. Social practice is the production of the relationship between habitus and the realm by involving capital in it.

Cultural capital is the entire intellectual qualification that can be produced through formal and non-formal education such as expertise in mastery of traditional Balinese architecture (ATB) by undagi, architects, and the community. For Bourdieu, cultural capital has dimensions of objective knowledge of arts and culture, cultural preferences and tastes, skills and technical knowledge of culture. Cultural capital provides discourse and serves as a platform for maintaining traditional Balinese architecture through their knowledge. Armed with the education and skills of the architects/undagi and the people of Bali, they can become a strength of cultural capital so that traditional Balinese architecture can remain strong and sustainable. The results of research on the restoration process carried out by the people of Guwang Sukawati, Gianayar Regency, show that the cultural capital owned by the architects/undagi and the community provides strength in realizing the restoration of the temple heritage architecture with the restoration process. This can be seen from I.B. Alita (56 years), one of the architects/undagi of the restoration of Pura Desa and Pura Puseh in Guwang Village, Sukawati, Gianyar as follows.

... I and the architects and cultural heritage team always provide an example to the people of Guwang Sukawati Village, Gianyar Regency regarding the importance of the nation's cultural heritage and the historical development of heritage architecture in Bali. Providing education to the public to maintain and preserve the heritage architecture in Bali and continue to do this through outreach to the community to increase awareness of the importance of historical buildings. For us architects/undagi play a role in minimizing the loss of cultural heritage buildings due to the lack of knowledge possessed by the community. Communities that have historical value from old sites in several places in Bali have not been destroyed, but the implementation process is used intelligently and wisely (Interview, 6 August 2018).

The same thing was conveyed by Bendesa Adat Desa Guwang, Sukawati Gianyar I Ketut Karben Wardana (53 years old) as below.

.... The entire community in Guwang Village has agreed to restore the Village Temple and Puseh Temple because they want to be committed to continually maintaining and preserving historical buildings to remain sustainable. Especially in our 
village, many carving artists aged around 80-90 care about the temple's heritage architecture, which has high historical value. This can be proven by their involvement in making carvings independently by artists and senior leaders (who are old) from Guwang Traditional Village (Interview, 6 August 2018).

Based on the results of the interviews with the two informants above, a framework of thought can be built that cultural capital plays a fairly central role in social power relations in maintaining buildings that have a high history. The potential of human resources through creativity and innovation can be used as a strength of cultural capital to preserve heritage architecture in Bali. The traditions and local wisdom of traditional Balinese architecture that are inherited from the people in Bali can be used as cultural capital for the development and preservation of traditional Balinese architecture. Architects/undagi have the cultural capital to educate the public that we should not lose and forget history. The cultural values possessed by our ancestors must be preserved, and we always respect nature, the environment, and the socio-culture.

Meanwhile, according to [1], symbolic capital is a form of recognition by groups, either institutionally or non-institutionally. The symbol itself has the power to construct reality, which can lead people to believe, acknowledge and change their view of reality. Symbolic capital can play a role in establishing power relations in the system and structure of society. The power of symbolic capital is used by the community in maintaining traditional Balinese architecture. Bourdieu's analysis of symbolic capital represented in traditional Balinese architecture will be challenging to undo if the community has extended solid relationships and systems supported by cultural forces in society.

Bourdieu [1] has emphasized that symbolic power is built through the hereditary results that the people in Bali have carried out. Symbolic violence can occur when another thought emerges from the community to replace traditional Balinese architecture with other materials such as black stone. It is solid and easy to maintain. This motivation tends to dominate in terms of economic benefits. The dominance of financial capital and symbolic capital played by the government over cultural capital has eroded and obscured the concept of preserving the architecture of the temple heritage. It is rational because according to [1] the arena of cultural production is one of the arenas in society. The arena of the artistic output is an arena for power struggles to compete and work so that the domination structure changes or remains lasting. The symbolic strength lies in the traditional leaders and penglisir Desa Guwang. They have a powerful desire to maintain the Village Temple and Puseh to stay in their original form through the restoration process.

The community owns social capital through a network of connections, solidarity, and emotion. It creates cooperation to jointly carry out the restoration process to preserve temple heritage buildings. Through social relations owned by the people of Guwang Village, they can collaborate with the dedicated team of the Indonesian Architects Association (IAI) Bali to collaborate on restoration planning and educate the community on the importance of restoration. This cooperation is carried out jointly to support each other through a typical interrelation pattern that is built on trust. The network that connects individuals with society does not just appear, but is the result of interactions, both individually and collectively, carried out with full awareness.
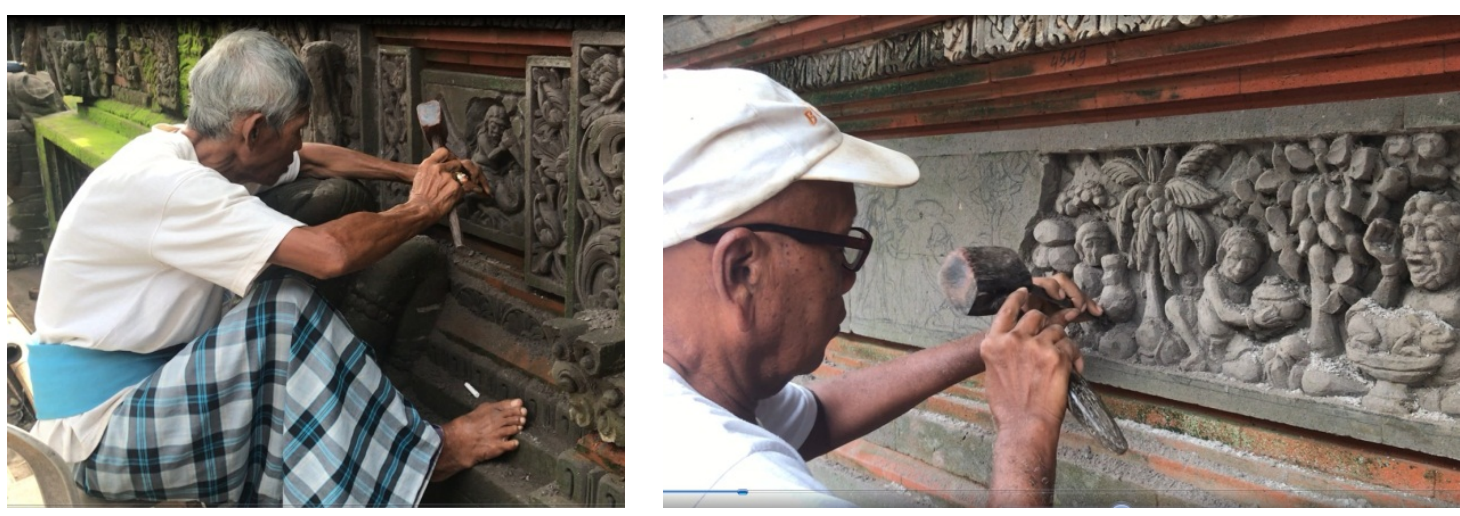

Source: Author, 2019.

Figure 9. The carving process is carried out in a ngayah (swadaya) manner by an 80-90-year-old artist of the Traditional Village of Guwang. 


\section{Conclusions}

Architecture plays an essential role in various aspects of life and becomes evidence to trace the nation's history. Architectural work also symbolizes creativity which is a combination of art, culture, and technology. Many efforts have been made to encourage the preservation of historical buildings, including preserving the architectural style of Balinese temples. The rich potential of natural resources, cultural diversity, and human resources needs to be optimized through creativity and innovation as the strengths of cultural capital and symbolic capital to preserve heritage architecture in Bali.

Preservation of heritage architecture has become an obligation to be carried out through restoration activities so that future generations can still enjoy the heritage and cultural wealth of previous generations. Restoration activities are also expected to improve people's welfare by promoting cultural heritage in tourism activities at the national and international levels. In the future, all components of indigenous peoples and the government are always expected to maintain and preserve historic buildings so that they remain sustainable following the mandate of Law Number 11 of 2010 concerning Cultural Heritage.

The existence of traditional Balinese architecture can still be maintained; this shows that the power of cultural capital and symbolic capital is extreme. This fact proves that the structured space (arena) can continuously explore itself and reproduce culture. According to [1], cultural capital is closely related to symbolic capital because they support each other in the hall. Guwang Village's symbolic strength is to use its cultural capital, such as the capacity to practice and understanding of traditional Balinese architecture, by penglisir (the elder in the village) by setting an example for the next generation about the significance of preserving traditional Balinese architecture.

\section{REFERENCES}

[1] Bourdieu, P., Arena of Cultural Production, A Study of Cultural Sociology. Fourth. Edited by I. R. Muzir. Bantul: Discourse Creation, 2016.

[2] Budihardjo and Sidharta, Environmental Conservation and Historical Ancient Buildings in Surakarta. Yogyakarta: Gadjah Mada University Press, 1989.

[3] Moleong, J., Qualitative Research Methodology. Bandung: PT Remaja Rosdakarya, 2012.

[4] Putri, N. P. R. P. A. and Widiantara, I. P. A., "Conservation Strategies to Maintain the Identity of Site Temple Architecture in Sibang Village (Reduction of Social, Economic, and Architectural Risks)", Journal of Zoning Architecture, 2 (1), pp. 68-74, 2019.
[5] Law Number 11 of 2010 concerning Cultural Heritage, 2010.

[6] Ministerial Regulation No. 01/PRT/M/2015 concerning the Preserved Cultural Heritage Building, 2015.

[7] Bali Provincial Government, Bali Provincial Regulation No. 5, Year 2005 concerning Building Architectural Requirements, 2005.

[8] Ngakan Ketut Acwin Dwijendra. I Putu Gede Suyoga, "Analyze of Symbolic Violence Practices in Balinese Vernacular Architecture, Bali Indonesia", International Journal of Innovation, Creativity and Change, Vol. 13, Issue 5, 18 June 2020. Retrieved fromhttps://www.ijicc.net/imag es/vol_13/Iss_5/13543_Dwijendra_2020_E_R.pdf, 2020.

[9] M. V. Yogantari, N. K. A. Dwijendra, "Visual Exploration Using Acrylic Paint on Used Fashion Items for Sustainable Use", In: International Journal of Psychosocial Rehabilitation, Vol. 24, No. 03, DOI:10.37200/IJPR/V24I3 /PR201902, 2020.

[10] Ngakan Ketut Acwin Dwijendra, "From Tradition to Modernization in Morphological Process of Indigenous Settlement Patterns in Bali, Indonesia", International Journal of Advanced Science and Technology, 29(8s), 172 184. Retrieved fromhttp://sersc.org/journals/index.php/IJA ST/article/view/1043, 2020.

[11] N. P. S. Nurjani, N. K. A. Dwijendra, "How Traditional Balinese Houses Can Adjust and Cater for International Tourist in the Canggu Area, Bali Indonesia? In: International Journal of Psychosocial Rehabilitation, Vol. 24, No. 03, DOI: 10.37200/IJPR/V24I3/PR201901, 2020.

[12] I Kadek Merta Wijaya, "Effect Local Direction on Balinese Traditional Settlement Layout, Case Study: Pengotan Traditional Village in Bali, Indonesia," Civil Engineering and Architecture, Vol. 8, No. 6, pp. 1395 - 1407, 2020. DOI: $10.13189 /$ cea.2020.080622.

[13] N. K. A. Dwijendra, "Identity Struggle Perspective in Car-Shaped Shrine in Paluang Temple, Nusa Penida Bali, Indonesia", International Journal of Psychosocial Rehabilitation, Vol. 24, No. 4, DOI:10.37200/IJPR/V24I4/ PR201653, 2020.

[14] Wa Ode Sifatu, Herman Sjahruddin, Yana Fajriah, Ngakan Ketut Acwin Dwijendra, Adi Santoso, "Innovative Work Behaviors in Pharmacies of Indonesia: Role of Employee Voice, Generational Diversity Management and Employee Engagement", SRP; 11(2): 725-734. DOI: 10.31838/srp.2020.2.105. Retrieved fromhttp://sysrevphar $\mathrm{m}$. org/?mno=118846, 2020.

[15] Ngakan Ketut Acwin Dwijendra, Frysa Wiriantari, Desak Made Sukma Widiyani, Anak Agung Ayu Sri Ratih Yulianasari, Arya Bagus Mahadwijati Wijaatmaja, "Transformation of Catuspatha in Bali Indonesia: Alteration Ideas from Empty Space to Aesthetic Element of City", Rupkatha Journal on Interdisciplinary Studies in Humanities. Volume 12, Number 6, 2020. DOI:10.21659/rupkatha.v12n6.15, 2020.

[16] Adhika, I.M., Putra, I.D.G.A.D., "Reinvigorating cultural landscapes for planning cultural tourism in Bali", Geojournal of Tourism and Geosites, 2021, 33(4), pp. $1462-1469$. 
[17] Putra, I.D.G.A.D., Wirawibawa, I.B.G., Satria, M.W., Spatial orientation and the patterns of the traditional settlement in the eastern Bali: Investigating new tourism atractions, Geojournal of Tourism and Geosites, 2020, 29(2), pp. 614-627.

[18] Ngakan Made Anom Wiryasa, Ngakan Ketut Acwin Dwijendra, "Socio-Physical Transformation towards Sustainable Urban Morphology through Land Readjustment in Indonesia," Civil Engineering and Architecture, Vol. 9, No. 3, pp. 874 - 882, 2021. DOI: 10.13189/cea.2021.090329.

[19] Ida Bagus Gde Wirawibawa, I Dewa Gede Agung Diasana Putra, Ngakan Ketut Acwin Dwijendra, "Memada-mada: The Power Relation and Architectural Creativity of Gianyar Palace," Civil Engineering and Architecture, Vol. 9, No. 3, pp. 949 - 957, 2021. DOI: 10.13189/cea.2021.090336.

[20] I Nyoman Widya Paramadhyaksa, Ngakan Ketut Acwin Dwijendra, "The Complexity of Orientation in Traditional Village Architecture in Bali, Indonesia", Humanities Diliman, A Philippine Journal of Humanities, HD Vol. 18 No. 1, January-June 2021.

[21] Dwijendra, NKA, "Bali Traditional Housing and Settlements", Journal of Settlement Natah, Vol. 1 No. February 1, pp. 8 - 24, 2003.

[22] I Dewa Gede Agung Diasana Putra, I Made Adhika, Anak Agung Gde Agung Yana, "Reviving Cultural Tourism in Kendran Bali Indonesia: Maintaining Traditional Architecture and Developing Community-based Tourism," Civil Engineering and Architecture, Vol. 9, No. 2, pp. 328 338, 2021. DOI: 10.13189/cea.2021.090206.

[23] K. D. Bailey, Methods of Social Research, Fourteth Edition ed. New York: A Division of Macmillan Publishing Co. Inc., New York., 1994.

[24] W. L. Neuman, J. Lasser and E. Adams, Eds. Basic of Social Research Methods: Qualitative and Quantitative Approaches, Second Edition ed. Boston: Allyn and Bacon
Co., Boston, 2004.

[25] J. P. Spradley, C. A. Belmont, Ed. Participant Observation Revised Edition ed. United States: Cengage Learning, Inc., United States, 1980.

[26] J. Ziesel, I. Altman and D. Stokols, Eds. Inquiry by Design: Tools for Environment-Behaviour Research, First Edition ed. California: Cambridge University Press, California, 1978.

[27] Frysa Wiriantari, Ngakan Ketut Acwin Dwijendra, Desak Made Sukma Widiyani, Anak Agung Ayu Sri Ratih Yulianasari, Arya Bagus Mahadwijati Wijaatmaja, Transformation of Catuspatha (Crossroad) In Bali Indonesia: Alteration Ideas From Empty Space To Aesthetic Element Of City, Solid State Technology Volume: 63 Issue: 6 Publication Year: 2020.

[28] N. K. A. Dwijendra, S. A. Paturusi, and W. Widiastuti, "Cultural Value Transformation in Traditional Market Spatial Planning in City of Denpasar, Gianyar and Klungkung - Bali, Indonesia," Journal of Sustainable Development, 2017, doi: 10.5539/JSD.V10N4P97.

[29] I. D. G. A. D. Putra, N. K. A. Dwijendra, S. A. Paturusi, and I. M. A. Mahendra, "Elements of the Cultural Space as a Form Identity of Klungkung Urban Area, Bali, Indonesia," Journal of Social and Political Sciences, 2019, doi: 10.31014/AIOR.1991.02.02.86.

[30] I. G. N. A. Rajendra, N. K. A. Dwijendra, P. R. Salain, and A. Kurniawan, "The Effect of Dutch Colonial Architecture on Palace in Bali, Indonesia," Journal of Social and Political Sciences, 2019, doi: 10.31014/AIOR.1991.02.02.85.

[31] A. Kurniawan, P. R. Salain, N. K. A. Dwijendra, and I. G. N. A. Rajendra, "Revealing the meaning behind Mandala of Agung Karangasem Palace, Bali Indonesia: Investigating through semiotics for preservation of historic value," International Journal of Advanced Science and Technology, vol. 29, no. 7, 2020. 